\title{
OJㅡㄹ
}

Volume 4, Issue 1 (2021), pp. 89-96 International Journal of Entrepreneurship and Economic Issues ISSN: 2616-0048 Print/ ISSN: 2631-231X Online

\section{Leveraging Innovative Entrepreneurship in Shaping Nepal's Agriculture Sector post-COVID-19}

\author{
Rastraraj Bhandari \\ Peking University, China \\ Sangam Paudel \\ Yale-NUS College, Singapore
}

\begin{abstract}
The COVID-19 pandemic has exposed the fragility of Nepal's agricultural system and the urgent need to strengthen food security. This paper explores the primary constraints in Nepal's agricultural sector and presents innovative entrepreneurial strategies and solutions to alleviate said constraints. By strategically assessing existing value chains, engaging both the public and private sector, and by re-evaluating the migrant crisis as an opportunity, the paper highlights agri-business opportunities in Nepal postCOVID-19.
\end{abstract}

Keywords: agriculture, business, covid-19, entrepreneurship, livestock, Nepal

At present, agriculture in Nepal employs a smaller portion of the country's
workforce than in the past. This is in line with trends seen in developing
countries that intensify per capita agricultural production, while growing
and diversifying their economies (Federico, 2010). However, the subsequent
increase in household consumption in Nepal is supported not by more - 89 - 
competitive domestic value chains, but by imported products. For instance, over the past ten years, import of vegetables from India has witnessed an almost eight-fold increase (Ministry of Finance, 2019, p. 70). Such industrywide trends undermine Nepal's food security and pose a risk for the population, especially during times of crises, such as the Covid-19 pandemic.

However, such disruptions also present an opportunity for agribusinesses. As imports from India that usually displaced local produce waned during the Covid-19 induced lockdown, local farmers in Baglung gained a greater share of the market (Halokhabar, 2020). While such victories may be short-lived, they do present a glimpse into the possibility of an import substitution strategy that can leverage innovative entrepreneurship in the context of COVID-19 to significantly strengthen the nation's food security. This would not only provide much needed employment opportunities to the surplus labor added from people returning from the gulf but also reduce Nepal's dependency on its neighbors for agricultural products.

The essay proceeds as follows: First, the essay identifies access to markets as a fundamental obstacle towards Nepal's lack of self-sufficiency in agriculture. Second, the essay explores the new found dilemma of decreasing remittances but increasing labor surplus in Nepal as a result of the COVID-19 pandemic. The next section provides a case study for an effective agribusiness that can leverage public-private partnerships in the context of Nepal. Finally, the paper concludes.

\section{ACCESS TO MARKETS AS A FUNDAMENTAL OBSTACLE}

Nepal's agriculture sector is greatly affected by limited market access, as expressed in terms of distance to roads, market centers, agriculture centers, cooperative, and banks (Fig 1). Only the central and western regions are somewhat well-connected to the various agriculture-related infrastructure. This limited market access further lowers the competitive ability of the mostly small-scale Nepali farmers who are scattered over a difficult terrain. This results in Nepali farmers not getting appropriate prices for their hardearned produce, while consumers depend on cheap imports from India's robust supply chain. 


\begin{tabular}{|c|c|c|c|c|c|c|c|c|c|c|}
\hline \multirow[t]{2}{*}{ Region } & \multicolumn{2}{|c|}{$\begin{array}{c}\text { Dirt road } \\
\text { vehicle } \\
\text { passable }\end{array}$} & \multicolumn{2}{|c|}{$\begin{array}{l}\text { Market } \\
\text { Center }\end{array}$} & \multicolumn{2}{|c|}{$\begin{array}{l}\text { Agriculture } \\
\text { Center }\end{array}$} & \multicolumn{2}{|c|}{ Cooperatives } & \multicolumn{2}{|c|}{ Bank } \\
\hline & 2010 & 2003 & 2010 & 2003 & 2010 & 2003 & 2010 & 2003 & 2010 & 2003 \\
\hline Eastern & $\begin{array}{c}5.31 \\
(10.60)\end{array}$ & $\begin{array}{c}13.67 \\
(19.49)\end{array}$ & $\begin{array}{c}2.51 \\
(5.26)\end{array}$ & $\begin{array}{c}4.81 \\
(10.05)\end{array}$ & $\begin{array}{c}1.80 \\
(2.07)\end{array}$ & $\begin{array}{c}4.30 \\
(8.73)\end{array}$ & $\begin{array}{c}1.59 \\
(2.35)\end{array}$ & $\begin{array}{c}5.18 \\
(9.44)\end{array}$ & $\begin{array}{c}4.20 \\
(9.29)\end{array}$ & $\begin{array}{c}6.76 \\
(11.26)\end{array}$ \\
\hline Central & $\begin{array}{c}1.63 \\
(3.41)\end{array}$ & $\begin{array}{c}1.13 \\
(2.22)\end{array}$ & $\begin{array}{c}2.23 \\
(4.30)\end{array}$ & $\begin{array}{c}1.71 \\
(1.65)\end{array}$ & $\begin{array}{c}2.06 \\
(3.73)\end{array}$ & $\begin{array}{c}1.76 \\
(1.91)\end{array}$ & $\begin{array}{c}1.91 \\
(4.37)\end{array}$ & $\begin{array}{c}1.91 \\
(2.13)\end{array}$ & $\begin{array}{c}3.14 \\
(5.93)\end{array}$ & $\begin{array}{c}2.31 \\
(3.14)\end{array}$ \\
\hline Western & $\begin{array}{c}1.70 \\
(2.52)\end{array}$ & $\begin{array}{c}13.72 \\
(28.71)\end{array}$ & $\begin{array}{c}1.74 \\
(2.55)\end{array}$ & $\begin{array}{c}7.83 \\
(21.19)\end{array}$ & $\begin{array}{c}1.29 \\
(2.02)\end{array}$ & $\begin{array}{c}6.16 \\
(15.81)\end{array}$ & $\begin{array}{c}0.92 \\
(0.93)\end{array}$ & $\begin{array}{c}7.17 \\
(17.49)\end{array}$ & $\begin{array}{c}2.02 \\
(3.08)\end{array}$ & $\begin{array}{c}10.86 \\
(25.37)\end{array}$ \\
\hline $\begin{array}{l}\text { Mid- } \\
\text { Western }\end{array}$ & $\begin{array}{c}7.56 \\
(14.96)\end{array}$ & $\begin{array}{l}29.75 \\
(51.92)\end{array}$ & $\begin{array}{c}4.75 \\
(8.91)\end{array}$ & $\begin{array}{c}11.41 \\
(20.98)\end{array}$ & $\begin{array}{c}1.87 \\
(2.15)\end{array}$ & $\begin{array}{c}7.96 \\
(21.66)\end{array}$ & $\begin{array}{c}4.26 \\
(10.45)\end{array}$ & $\begin{array}{c}11.62 \\
(22.82)\end{array}$ & $\begin{array}{c}8.32 \\
(14.33)\end{array}$ & $\begin{array}{c}12.99 \\
(23.81)\end{array}$ \\
\hline $\begin{array}{l}\text { Far } \\
\text { Western }\end{array}$ & $\begin{array}{c}5.27 \\
(8.06)\end{array}$ & $\begin{array}{c}10.97 \\
(16.25)\end{array}$ & $\begin{array}{c}2.99 \\
(6.42)\end{array}$ & $\begin{array}{c}2.43 \\
(2.32)\end{array}$ & $\begin{array}{c}2.48 \\
(9.21)\end{array}$ & $\begin{array}{c}3.66 \\
(5.44)\end{array}$ & $\begin{array}{c}5.03 \\
(12.73)\end{array}$ & $\begin{array}{c}5.08 \\
(5.79)\end{array}$ & $\begin{array}{c}8.19 \\
(15.04)\end{array}$ & $\begin{array}{c}5.10 \\
(5.29)\end{array}$ \\
\hline
\end{tabular}

Figure 1: Distance to Infrastructure, Markets, and Agricultural Services (kilometers) (World Bank Group, 2016, p. 20)

The problem of market access is exacerbated by a chronic lack of storage areas for post-harvest produce, which forces farmers to sell their products early, at a low cost, even while the supply is high (International Labour Organization, 2019, p. 21). This shortage further hinders Nepal's efforts at agricultural self-sufficiency and presents itself as a bottleneck for increased agricultural productivity. Atop these problems, the COVID-19 pandemic highlights issues of animal infection, sanitation, and hygiene (The Lancet, 2020).

Despite recognizing lack of access to market as a stalling force behind Nepal's self-sufficiency, Nepal has not been able to effectively tackle this problem. The 2020-21 budget has shown positive signs by allocating increased spending on agriculture. There has been an increase in the budget for farming and irrigation to Rs 41 billion, while Rs 10 billion has been set aside to boost agriculture through various irrigation projects (Ministry of Finance, 2020). Policies ranging from relief packages for production, easy loans for farmers, agricultural extension advisory services for farmers, government support on insurance of crops and livestock, and minimum support prices for agricultural products have also been put forward. However, none of these efforts explicitly support an increased access to market for customers. 
The share of remittance and the agriculture sector continue to form the backbone of Nepal's GDP (fig2). From the FY 2006/07 to FY 2017/18, the government provided licenses to 4,365,415 migrant workers. This accounts for almost $15 \%$ of the country's total population (Ministry of Finance, 2019, p. 76).

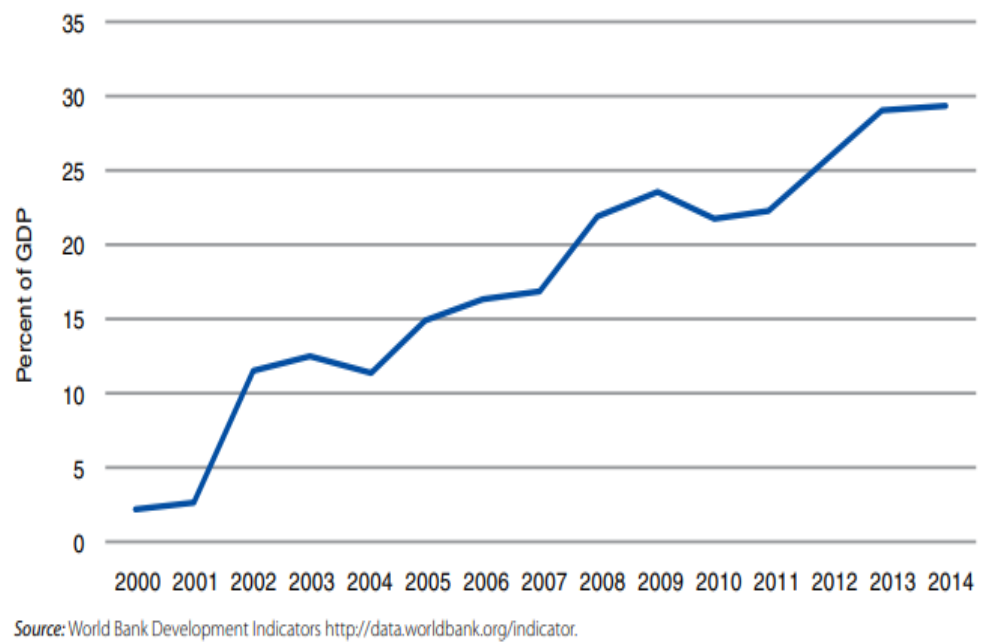

Figure 2: Remittances Income as Proportion of GDP (World Bank Group, 2016, p. 19)

On the other hand, there has been an overall decline in the production of agricultural commodities, especially in terms of net export of agricultural commodities. This is also accompanied by a decrease in the contribution of agriculture in Nepal's GDP, from above 40\% in 1995 to almost $30 \%$ by 2014 (Fig 3).

The COVID-19 crisis has severely affected the stream of remittances as many migrant workers have returned back to Nepal or expect to do so as the pandemic continues. According to a study by the Foreign Employment Board released in early May 2020, 127,000 migrant workers were expected to return to Nepal immediately, with another 407,000 to follow in the subsequent weeks (Mandal, 2020). This presents a dilemma; while remittance is likely to decrease in the coming years, there will be an increase in labor surplus in the country. When viewed in light of the massive 
growth in remittance as a proportion of GDP (Fig.2), the fragility of Nepal's agricultural sector becomes ominously clear. Therefore, there is an increased opportunity to leverage the added labor surplus into the agricultural sector given it can provide the cushion for added employment and productivity, which can eventually lead to self-sufficiency in food consumption in Nepal.

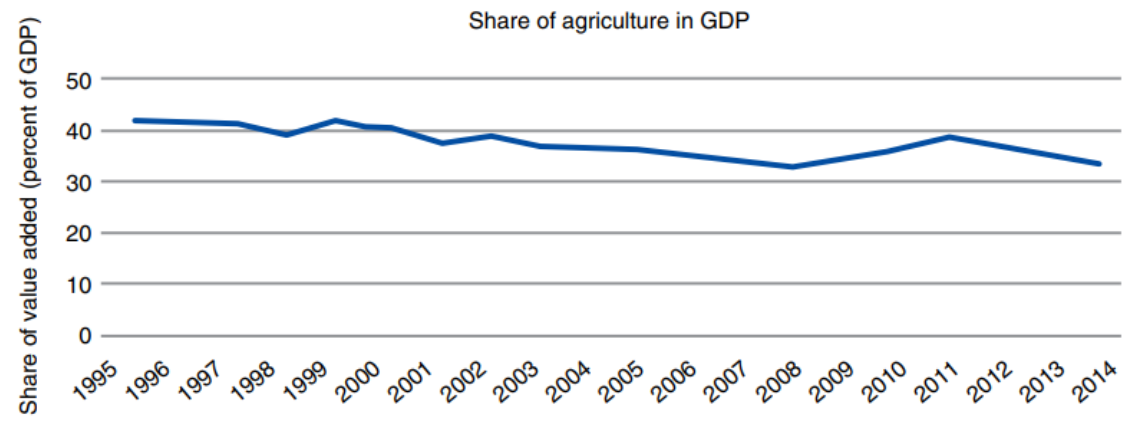

Figure 3: Share of agriculture in GDP (World Bank Group, 2016, p. 2)

What is less obvious is the mechanism through which the added labor can be leveraged into the agricultural sector. A multi-dimensional approach with incentives in the form of finance, technology, and policy will aid such a transition. However, besides incentives, education and entrepreneurship vis-à-vis the modernization of agricultural production needs to be utilized to build capacity among youths.

Linking technology with agriculture as part of pushing for entrepreneurial solutions is key in the Nepalese context. Dr Mahabir Pun's pioneering usage of Information and Communication Technology (ICT) in Agriculture to connect producers with the market is one such example of possible innovative solutions in tackling Nepal's agricultural constraints (Mahat, 2009). The resultant increased connectivity to the market can also be a further stimulus for increased productivity. While Nepal's Total Factor Productivity (TFP) has shown gradual increase since 1992, it still lags far behind that of India and Bangladesh, in most crops with the notable exception of fruits. Increased connectivity can aid in bridging this productivity gap (World Bank Group, 2016, p. 12).

The Prime Minister Agriculture Modernization Project needs to step beyond their incentive schemes and provide capacity building to these youths on how they can ideate towards solutions. It should capitalize on the observed tendency of some returning immigrants to invest in commercialized agriculture. The government must take a multi-stakeholder 
approach, involving relevant educational institutions in Nepal with a proven track record in building sustainable agri-businesses. To begin with, the government needs to identify the strengths and weaknesses of the returnees before designing effective solutions that suits their needs.

\section{CASE STUDY: AGRIBUSINESS OPPORTUNITIES IN THE LIVESTOCK SECTOR POST COVID-19}

With COVID-19 being traced to the wet market in China, countries around the world are paying increased attention to the animal husbandry sector $(\mathrm{Wu}$ et al., 2020). This is also likely to result in a greater consumer demand for increased sanitation and health procedures in the supply chain. In the meat sector, slaughterhouses that meet health standards might enjoy an advantage over the status-quo slaughterhouses.

The legislation that governs slaughterhouse standards in Nepal - the Animal Slaughterhouse and Meat Inspection Act, 2055 (1999) - contains sections that necessitate ante-mortem examination for diseases (Department of Livestock Services, 1999). While progressive and ambitious, the Act has not been properly enforced. However, heightened consumer concern and possible co-benefits from increased regulations - including disease prevention, higher meat standard, and increased ease in export - will likely present opportunities for sanitary slaughterhouses in the country.

Amidst this backdrop, a possibility could be to leverage PublicPrivate Partnerships (PPP) to identify agribusiness opportunities in a post COVID-19 Nepal. Public-Private Parterships aid value chain development (VCD) by capitalizing on the private sector's propensity for attaining economic and operational efficiency and complementing it with the public sector's ability to create conducive conditions for development of commodity chains (FAO, 2016, p. ix).

Meso-level VCDs that seek to revitalize existing production areas for large-scale commodities are especially attractive to fill gaps in the livestock sector's value chain (FAO, 2016, p. 29). Considering the deficit of livestock products in the country, coupled with a great amount of barren lands in the hills and an influx of migrant workers, grass production/storage enterprises present themselves as promising prospects. Supplying grass products to farms would revitalize degraded hill soils, relieve farms of timeconsuming fodder concerns, and the replacement of conventional feed with grass inputs would increase the output of livestock products. Initially, the production aspects of these efforts may have to be supported by targeted programs of the public sectors through training and workshops, some of 
which may already exist. The private sector could retain control over midstream and downstream activities.

\section{CONCLUSION}

In the aftermath of COVID-19, it is therefore important to look at the entire supply chain to identify opportunities within the agricultural sector. It may be valuable to look for bottlenecks that decrease the productivity of the sector. Bottlenecks such as long-term storage units or transportation hurdles yield themselves well to innovative agri-business opportunities and local employment. These efforts do require active and ambitious support from the government in terms of incentives, capacity development, and regulations and their enforcement. However, if provided, there is an increased opportunity to develop the various agricultural sectors such that they contribute to greater local employment and increased food security.

\section{REFERENCES}

Department of Livestock Services, Government of Nepal. (1999). Animal Slaughterhouse and Meat Inspection Act, 2055.

FAO. (2016). Public-private partnerships for agribusiness development-A review of international experiences. FAO.

Federico, G. (2010). Feeding the World: An Economic History of Agriculture, 1800-2000. Princeton University Press.

Halokhabar. (2020, May 31). "As import ceases, local vegetables gain market." Halokhabar. Retrieved June 21, 2020, from https://halokhabar.com//news-details/4259/2020-05-31

ICT for Rural Community Development - Interview with Mahabir Pun [Interview by T. J. Mahat]. (2009). Retrieved June 21, 2020, from https://lib.icimod.org/record/14486

International Labour Organization. (2019). Eight Ways to Grow Nepal's Agricultural Sector. ILO.

Mandal, C. K. (2020, May 9). Thousands of Nepali migrant workers from Persian Gulf and Malaysia expected to return home soon. The Kathmandu Post. Retrieved June 21, 2020, from https://kathmandupost.com/national/2020/05/09/thousands-ofnepali-migrant-workers-from-persian-gulf-and-malaysia-expectedto-return-home-soon

Ministry of Finance, Government of Nepal. (2019) Economic Survey 2018/19. 
Ministry of Finance, Government of Nepal. (2020, May 28). Budget Speech FY 2020-21.

The Lancet. (2020). Redefining vulnerability in the era of COVID-19.

Lancet (London, England), 395(10230), 1089-1089. PubMed.

https://doi.org/10.1016/S0140-6736(20)30757-1

World Bank Group. (2016). Nepal: Sources of Growth in Agriculture for Poverty Reduction and Shared Prosperity. World Bank.

https://doi.org/10.1596/28333

Wu, Y. C., Chen, C. S., \& Chan, Y. J. (2020). The outbreak of COVID-19:

An overview. Journal of the Chinese Medical Association, 83(3), 217.

RASTRARAJ BHANDARI is a Yenching Scholar at Peking University. Email:rb3598@nyu.edu.

SANGAM PAUDEL is an environmental studies student at Yale-NUS College in Singapore. Email: e0191993@u.nus.edu.

Manuscript submitted: June 25, 2020

Manuscript revised: July 15, 2020

Accepted for publication: August 15, 2020 